\title{
Prenylated Flavonoids from the Root Bark of Berchemia discolor, a Tanzanian Medicinal Plant
}

\author{
Young-Won Chin $\dagger$, Ladislaus K. Mdee $\ddagger$,, Zakaria H. Mbwambo $§$, Qiuwen Mi $\ddagger$, Hee-Byung \\ Chai ${ }^{\dagger}, \ddagger$, Gordon M. Cragg ${ }^{\perp}$, Steven M. Swanson $\ddagger$, and A. Douglas Kinghorn ${ }^{\star}, \dagger, \ddagger$ \\ Division of Medicinal Chemistry and Pharmacognosy, College of Pharmacy, The Ohio State \\ University, Columbus, Ohio 43210, Program for Collaborative Research in the Pharmaceutical \\ Sciences and Department of Medicinal Chemistry and Pharmacognosy, College of Pharmacy, \\ University of Illinois at Chicago, Chicago, Illinois 60612, Institute of Traditional Medicine, Muhimbili \\ University College of Health Sciences, Dar es Salaam, Tanzania, and National Cancer Institute, \\ NCl-Frederick, Fairview Center, P. O. Box B, Frederick, Maryland 21702
}

\begin{abstract}
Five new prenylated flavonoids (1-5) were isolated from the root bark of Berchemia discolor, collected in Tanzania, along with 10 known compounds, by bioactivity-guided fractionation. The structures of compounds (1-5) were elucidated using various spectroscopic techniques. Of these isolates, compound 4, and the known compounds, nitidulin (6), amorphigenin (7), and dabinol (8), exhibited cytotoxic activity when evaluated against a small panel of human cancer cells. Nitidulin (6) was further tested in an in vivo hollow fiber assay, and found to be active against LNCaP (human hormone-dependent prostate cancer) cells implanted intraperitoneally, at doses of 10,20, and $40 \mathrm{mg} /$ $\mathrm{kg}$.
\end{abstract}

The species Berchemia discolor (Klotzsch) Hemsl. (Rhamnaceae), distributed in Africa and the Arabian peninsula, is a shrub or small tree. ${ }^{1,2}$ The fruits are edible and the leaves are used to make beverages. Also, this plant is a good source of timber and of a dye material. ${ }^{3}$

Ethnobotanically, an aqueous extract of the stem bark of $B$. discolor, is boiled with the whole roots of Cordia crenata Delile (Boraginaceae) and Tamarindus indica L. (Caesalpiniaceae), and administered in divided doses to treat malaria in Tanzania. ${ }^{4}$

There have been no previous investigations on the bioactive secondary metabolites of $B$. discolor. As part of a systematic search for anticancer agents of plant origin, ${ }^{5}$ the root bark of this species, collected in Tanzania, where it is known as "mukuni", was selected for activityguided fractionation, following an initial screen of a $\mathrm{CHCl}_{3}$-soluble extract using the $\mathrm{LNCaP}$ (hormone-dependent human prostate cancer) cell line. Bioactivity-guided fractionation of this extract using this same cell line led to the isolation of five new prenylated flavonoids (1-5) and 10 known compounds. Herein, the structure elucidation of these new substances and their biological evaluation as potential anticancer agents, are described.

The structures of the known compounds were identified by physical and spectroscopic data measurement $\left([\alpha]_{\mathrm{D}}, \mathrm{CD},{ }^{1} \mathrm{H}\right.$ NMR, ${ }^{13} \mathrm{C} \mathrm{NMR}, 2 \mathrm{D}$ NMR, and MS) and by comparing the data obtained with published values, as nitidulin $(\mathbf{6}),{ }^{6}$ amorphigenin $(\mathbf{7}),{ }^{7}$ dabinol $(\mathbf{8}),{ }^{7}$

\footnotetext{
*To whom correspondence should be addressed. Tel.: +1 614247 8094. fax: +1 614247 8081. E-mail address: kinghorn.4@ osu.edu.

$\dagger$ The Ohio State University

WUniversity of Illinois at Chicago.

$\S_{\text {Muhimbili University College of Health Science. }}$

$\perp_{\text {National Cancer Institute. }}$
} 
heminitidulan, ${ }^{6}$ 3-hydroxy-4'-O-methylglabridin, ${ }^{8} 4^{4}$-hydroxycabenegrin A-I, ${ }^{9}$ leiocarpin, ${ }^{6}$ leiocin, ${ }^{6}$ leiocinol, ${ }^{6}$ and nitidulan. ${ }^{6}$

Compound $\mathbf{1}$ was isolated as an amorphous solid, and its molecular formula of $\mathrm{C}_{21} \mathrm{H}_{18} \mathrm{O}_{6}$ was deduced from a sodiated molecular ion peak observed at $\mathrm{m} / \mathrm{z} 389.0974$ (calcd for $\left.\mathrm{C}_{21} \mathrm{H}_{18} \mathrm{O}_{6} \mathrm{Na}^{+}, 389.0996\right)$. In the ${ }^{1} \mathrm{H}$ NMR spectrum of $\mathbf{1}$, the signals at $\delta_{\mathrm{H}} 3.40$ (m, H-6a), 3.55 (t, $J=10.8 \mathrm{~Hz}, \mathrm{H}-6), 4.14$ (dd, $J=10.8,4.8 \mathrm{~Hz}, \mathrm{H}-6)$, and 5.35 (d, $J=6.9 \mathrm{~Hz}, \mathrm{H}-11 \mathrm{a})$ were assigned to $\mathrm{H}-6 \mathrm{a}, \mathrm{H}_{2}-6$, and $\mathrm{H}-11 \mathrm{a}$ of a pterocarpan skeleton. ${ }^{10}$ When compared to the ${ }^{1} \mathrm{H}$ NMR chemical shifts of leiocarpin, ${ }^{10}$ which was also isolated and identified in the present investigation, the ${ }^{1} \mathrm{H}$ NMR spectroscopic data of the two compounds were similar, except that there was a singlet aromatic proton peak at $\delta_{\mathrm{H}} 6.85$ and a hydroxy group signal at $\delta_{\mathrm{H}} 5.08$ in the A ring of 1 instead of two ortho-coupled protons in leiocarpin. The position of a hydroxy group in 1 was inferred as $\mathrm{C}-2$ of ring A by the observed HMBC correlations of $\mathrm{H}-1$ to $\mathrm{C}-11 \mathrm{a}\left(\delta_{\mathrm{C}} 78.8\right), \mathrm{C}-2\left(\delta_{\mathrm{C}} 139.5\right), \mathrm{C}-3\left(\delta_{\mathrm{C}} 140.4\right)$, and C- $4 \mathrm{a}\left(\delta_{\mathrm{C}} 144.5\right)$ (Figure 1$)$. The absolute configurations of C-6a and C-11a were determined to be $S$ and $S$, respectively, based on a comparison of the $\mathrm{CD}$ curve of compound $\mathbf{1}$ with literature data. ${ }^{10}$ Thus, the new compound $\mathbf{1}$ was assigned structurally as $(6 a S, 11 \mathrm{a} S)$-1-hydroxyleiocarpin.

The HRESIMS of 2 provided a sodiated molecular ion peak at $\mathrm{mlz} 405.0936$, corresponding to an elemental formula of $\mathrm{C}_{21} \mathrm{H}_{18} \mathrm{O}_{6} \mathrm{Na}$. The ${ }^{1} \mathrm{H}$ NMR spectrum (Table 1) showed signals at $\delta_{\mathrm{H}} 4.90(\mathrm{dd}, J=12.0,3.1 \mathrm{~Hz}, \mathrm{H}-2 \mathrm{a}), 4.77$ (dd, $\left.J=12.0,4.6 \mathrm{~Hz}, \mathrm{H}-2 \mathrm{~b}\right)$, and 3.98 (brt, $J=3.6$ $\mathrm{Hz}, \mathrm{H}-3$ ), assignable to the C-ring of an isoflavanone. ${ }^{11}$ Also observed were a singlet peak at $\delta_{\mathrm{H}} 5.99$ (H-6) accounting for a pentasubstituted aromatic ring, and two singlet peaks at $\delta_{\mathrm{H}} 6.57$ (H-3') and 7.01 (H-6') of a 1,2,4,5-tetrasubstituted aromatic ring. Signals belonging 0to a 2,2dimethylpyran ring were observed at $\delta_{\mathrm{H}} 6.63\left(1 \mathrm{H}, \mathrm{d}, J=10.1 \mathrm{~Hz}, \mathrm{H}-1^{\prime \prime}\right), 5.55(1 \mathrm{H}, \mathrm{d}, J=10.1$ $\left.\mathrm{Hz}, \mathrm{H}-2^{\prime \prime}\right), 1.47$ (3H, s, H-5"), and 1.45 (3H, s, H-4"), and two singlet peaks at $\delta_{\mathrm{H}} 5.93$ and 5.91 were assigned to a methylenedioxy group. An isoflavanone skeleton with a pyran ring was inferred from these data. The ${ }^{13} \mathrm{C}$ NMR, DEPT, and HMQC data supported the presence of an isoflavanone structure. The observed $\mathrm{HMBC}$ correlations from $\delta_{\mathrm{H}} 11.72(\mathrm{OH}-5)$ to $\delta_{\mathrm{C}}$ 98.4 (C-6), 101.6 (C-10), and 165.1 (C-5) enabled the pyran ring to be placed between C-7 and C-8. Furthermore, correlations of H-6 and C-7, H-2" and C-8, and H-2 and C-9 supported the location of this pyran ring. The methylenedioxy group was positioned from the observed correlations between $\delta_{\mathrm{H}} 5.93$ and 5.91 to $\delta_{\mathrm{C}} 142.5\left(\mathrm{C}-5^{\prime}\right)$ and $148.5\left(\mathrm{C}-4^{\prime}\right)$. Since compound 2 exhibited a specific rotation of zero and no Cotton effects were observed in its CD spectrum, this compound was considered to be a racemate. Thus, the structure of $\mathbf{2}$, named discoloranone A, was assigned as 5,2'-dihydroxy-3',4'-methylenedioxy- 3", 3 "-dimethylpyrano [7,8 ] isoflavanone.

The molecular formula of $\mathbf{3}$ was found to be the same as $\mathbf{2}$ by the observed sodiated molecular ion peak at $m / z, 405.0950$ (calcd for $\mathrm{C}_{21} \mathrm{H}_{18} \mathrm{O}_{7} \mathrm{Na}, 405.0945$ ) in the HRESIMS. The ${ }^{1} \mathrm{H}$ and ${ }^{13} \mathrm{C}$ NMR data of these two compounds were very similar, except for differences in the chemical shifts of C-5, C-6, C-8, and C-9 (Table 1). This implied that the pyran ring in 3 is located at a different position when compared to 2 . The HMBC correlations of OH-5 to C-5, C-6, and C-9, and H-2" to C-6 were supportive of the attachment of the pyran ring to C-6 and C-7 instead of C-7 and C-8. Full assignments of ${ }^{1} \mathrm{H}$ and ${ }^{13} \mathrm{C}$ NMR chemical shifts were accomplished with the aid of DEPT, HMQC, and HMBC experiments. The absolute configuration of 3 at C-3 was determined to be $S$ from the CD spectrum. ${ }^{10}$ All of these data helped finalize the structure of $\mathbf{3}$, named isodiscoloranone A, as $(3,5)-5,2^{\prime}$-dihydroxy-3', $4^{\prime}$ methylenedioxy-3",3"-dimethylpyrano [6,7]isoflavanone.

A sodiated ion peak of $\mathbf{4}$ in the HRESIMS was observed at $m / z 475.1719$, accounting for an elemental formula of $\mathrm{C}_{26} \mathrm{H}_{18} \mathrm{O}_{7} \mathrm{Na}$. The ${ }^{1} \mathrm{H}$ NMR spectrum of $\mathbf{4}$ (Table 2) displayed characteristic signals of an isoflavanone at $\delta_{\mathrm{H}} 4.76(\mathrm{dd}, J=11.1,8.7 \mathrm{~Hz}, \mathrm{H}-2 \mathrm{a}), 4.62(\mathrm{dd}, J=$ 
11.1, 5.7 Hz, H-2b), and 4.22 (dd, $J=8.7,5.7 \mathrm{~Hz}, \mathrm{H}-3$ ), and gave evidence for the presence of a pyran ring and a prenyl group connected to the pyran ring. Two ortho-coupled signals at $\delta_{\mathrm{H}} 6.50\left(\mathrm{~d}, J=8.1 \mathrm{~Hz}, \mathrm{H}-5^{\prime}\right)$ and $6.75\left(\mathrm{~d}, J=8.1 \mathrm{~Hz}, \mathrm{H}-6^{\prime}\right)$ were assigned to the B-ring. Besides these signals, a hydroxy peak at $\delta_{\mathrm{H}} 12.12(\mathrm{OH}-5)$ and an $O$-methyl peak at $\boldsymbol{\delta}_{\mathrm{H}} 3.89$ were observed. The positions of the pyran ring and the prenyl group were confirmed by the HMBC correlations as shown in Figure 1. The ${ }^{3} J$ correlation of H-6" $\left(\delta_{\mathrm{H}} 2.08\right)$ to C-3" $(\delta \mathrm{c} 80.7)$ suggested that the prenyl group was affixed to the pyran ring. The $\mathrm{H}-2$ and $\mathrm{H}-1$ " proton signals exhibited correlations with the same carbon signal (C-9), and enabled the pyran ring to be located between C-7 and C-8. The $O$-methyl resonance at $\boldsymbol{\delta}_{\mathrm{H}} 3.89$ exhibited NOESY correlations with the proton at $\boldsymbol{\delta}_{\mathrm{H}} 6.50\left(\mathrm{H}-5^{\prime}\right)$, which confirmed the position of the methoxy group at $\mathrm{C}-4$ ' on the $\mathrm{B}$ ring. The absolute configuration of C-3 was determined to be $S$ based on the negative Cotton effect at $312 \mathrm{~nm}$ in the $\mathrm{CD}$ spectrum. ${ }^{10}$ Based on the data obtained, the structure of compound 4 (discoloranone B) was elucidated as (3,S)-5, $2^{\prime}, 3^{\prime}$-trihydroxy-4'methoxy-3"-methyl-3"-(4-methylpent-3-enyl)-pyrano[7,8]isoflavanone.

The molecular formula of compound $\mathbf{5}$ was assigned as the same as that of compound $\mathbf{4}$ by the observed sodiated ion peak in the HRESIMS, and the ${ }^{1} \mathrm{H}$ and ${ }^{13} \mathrm{C}$ NMR data (Table 2) of these two compounds were almost identical. Differences were observed due to the different location of the pyran ring in an analogous manner to compounds $\mathbf{2}$ and $\mathbf{3}$. The HMBC spectroscopic data displayed correlations of $\mathrm{H}-8$ to $\mathrm{C}-9$, and $\mathrm{H}-2$ to $\mathrm{C}-9$ through two-bond and three-bond proton-carbon couplings, respectively. The $\mathrm{S}$-absolute configuration at $\mathrm{C}-3$ was the same as that of compound $\mathbf{4}$ from the observed negative Cotton effect in the CD spectrum. ${ }^{10}$ Accordingly, the structure of compound $\mathbf{5}$ (isodiscoloranone B) was determined as (3S)-5, $2^{\prime}$, 3'-trihydroxy-4'-methoxy-3"-methyl-3"-(4-methylpent-3-enyl)-pyrano[6,7]isoflavanone.

All isolates obtained in this investigation from $B$. discolor root bark were evaluated for cytotoxicity against three human cancer cell lines (Lu1, LNCaP, and MCF-7). Among them, compounds 4 and 6-8 exhibited cytotoxic activity (ED5 $0 \leq 5 \mu \mathrm{g} / \mathrm{mL}$ ) for one or more cancer cell lines (Table 3). Since compound $\mathbf{6}$ was active in three human cancer cell lines and isolated in a reasonably large quantity, this compound was chosen for follow-up evaluation in an in vivo hollow fiber assay, which is used as a secondary discriminator bioassay in our program on the discovery of plant anticancer agents. ${ }^{12}$ Hollow fibers containing either Lu1, LNCaP, or MCF-7 cells were propagated subcutaneously or within the peritoneum of immunodeficient mice. The animals were treated with vehicle or nitidulin (6) once daily by ip injection $(10,20$, $40 \mathrm{mg} / \mathrm{kg}$ ) from day 3-6 after implantation. On day 7, mice were sacrificed, fibers were retrieved and analyzed as described in the Experimental Section below. Nitidulin (6) inhibited the growth only of the LNCaP cell line (49-52\%), propagated within the intraperitoneal site, at all doses tested. The compound was not active against any of the lines propagated subcutaneously (Figure S1, Supporting Information).

\section{Experimental Section}

\section{General Experimental Procedures}

Optical rotations were measured with a Perkin-Elmer 241 automatic polarimeter. UV spectra were obtained with a Perkin Elmer UV/Vis spectrometer lambda 10. Circular dichroism (CD) spectra were recorded on JASCO J-810 spectropolarimeter. IR spectra were run on an ATI Mattson Genesis Series FT-IR spectrophotometer. NMR spectroscopic data were recorded at room temperature on Bruker Avance DPX-300 and DRX-400 spectrometers with tetramethylsilane (TMS) as internal standard. Electrospray ionization (ESI) mass spectrometric analyses were performed with a 3-Tesla Finnigan FTMS-2000 Fourier Transform mass spectrometer, and electron impact (EI) ionization was performed with a Kratos MS-25 mass spectrometer, using $70 \mathrm{eV}$ ionization conditions. A SunFire ${ }^{\mathrm{TM}} \mathrm{PrepC}_{18} \mathrm{OBD}^{\mathrm{TM}}$ column $(5 \mu \mathrm{m}$, $150 \times 19$ mm i.d., Waters, Milford, MA) and a SunFire ${ }^{\mathrm{TM}} \mathrm{PrepC}_{18}$ guard column $(5 \mu \mathrm{m}, 10 \times 19$ 
mm i.d., Waters) were used for preparative HPLC, along with two Waters 515 HPLC pumps and a Waters 2487 dual $\lambda$ absorbance detector (Waters). Column chromatography was carried out with Purasil ${ }^{\circledR}$ (230-400 mesh, Whatman, Clifton, NJ) and Sephadex LH-20 (Sigma, St. Louis, MO). Analytical thin-layer chromatography (TLC) was performed on precoated 250 $\mu \mathrm{m}$ thickness Partisil ${ }^{\circledR} \mathrm{K} 6 \mathrm{~F}$ (Whatman) glass plates, while preparative thin-layer chromatography was conducted on precoated $20 \times 20 \mathrm{~cm}, 500 \mu \mathrm{m}$ Partisil ${ }^{\circledR} \mathrm{K} 6 \mathrm{~F}$ (Whatman) glass plates.

\section{Plant Material}

The root bark of B. discolor was collected at Limbura Village, Urambo District, Tabora Region, Tanzania, in September 1999. The plant was identified by H.O. Suleiman, and a voucher specimen (collection number IMPP 002-0143) has been deposited at the Herbarium of the Institute of Traditional Medicine, Muhimbili University College of Health Science, Dar es Salaam, Tanzania.

\section{Extraction and Isolation}

The dried and milled root bark of B. discolor $(1 \mathrm{~kg})$ was extracted by maceration with $\mathrm{MeOH}$ three times at room temperature, for up to 2 days each, and then evaporated in vacuo. The dried $\mathrm{MeOH}$ extract $(78 \mathrm{~g})$ was suspended with a mixture of $\mathrm{MeOH}-\mathrm{H}_{2} \mathrm{O}(9: 1,400 \mathrm{~mL})$ and partitioned sequentially with petroleum ether $(3 \times 200 \mathrm{~mL})$ and $\mathrm{CHCl}_{3}(3 \times 200 \mathrm{~mL})$.

The $\mathrm{CHCl}_{3}$-soluble partition was washed with $1 \%$ saline solution and concentrated under a vacuum to yield a $\mathrm{CHCl}_{3}$ extract $(15.3 \mathrm{~g})$, which exhibited cytotoxic activity $(2.6 \mu \mathrm{g} / \mathrm{ml})$ against the $\mathrm{LNCaP}$ cell line. The $\mathrm{CHCl}_{3}$-soluble fraction $(15.0 \mathrm{~g})$ was chromatographed over a vacuum silica gel column, using a gradient of increasing polarity with $\mathrm{CHCl}_{3}$ and acetone as solvents and was fractionated into seven sub-fractions (F01-F07). Cytotoxic activity of these subfractions was monitored using the $\mathrm{LNCaP}$ cell line, and three fractions (F01, F02, and F03, 2.6, 3.9, and $3.5 \mu \mathrm{g} / \mathrm{mL}$, respectively) were deemed to be active. Fraction F01 (323 mg) was subjected to column chromatography using Sephadex LH-20 with the solvent of $\mathrm{CH}_{2} \mathrm{Cl}_{2}$ $\mathrm{MeOH}(2: 1)$ and afforded seven sub-fractions (F0101-F0107). The constituents of sub-fraction F0107 were purified by HPLC. This separation was conducted with $\mathrm{MeOH}-\mathrm{H}_{2} \mathrm{O}$ (70:30), 7.0 $\mathrm{mL} / \mathrm{min}$, by isocratic elution for $20 \mathrm{~min}$, then increasing from 70:30 to 100:0 for $30 \mathrm{~min}$, and finally $100 \% \mathrm{MeOH}$ for $15 \mathrm{~min}$, to afford compounds 1 ( $\mathrm{t}_{\mathrm{R}} 27.7 \mathrm{~min}, 2.8 \mathrm{mg}$ ), 4'hydroxycabenegrin A-I ( $\left.\mathrm{t}_{\mathrm{R}} 36.8 \mathrm{~min}, 1.0 \mathrm{mg}\right)$, leiocarpin $\left(\mathrm{t}_{\mathrm{R}} 42.6 \mathrm{~min}, 70 \mathrm{mg}\right)$, nitidulin $(6$, $t_{R} 48.8 \mathrm{~min}, 45 \mathrm{mg}$ ), nitidulan ( $t_{\mathrm{R}} 50.5 \mathrm{~min}$ ), and heminitidulan ( $\mathrm{t}_{\mathrm{R}} 51.5 \mathrm{~min}, 0.8 \mathrm{mg}$ ). Fraction F02 (1.84 g) was subjected to column chromatography $(55 \times 150 \mathrm{~mm})$ using Sephadex LH-20 $\mathrm{CH}_{2} \mathrm{Cl}_{2}-\mathrm{MeOH}$ (2:1) as solvent, and to afford 13 sub-fractions (F0201-F0213). From subfraction F0212, leiocinol ( $\left.\mathrm{t}_{\mathrm{R}} 20.7 \mathrm{~min}, 9 \mathrm{mg}\right), \mathbf{4}\left(\mathrm{t}_{\mathrm{R}} 46.7 \mathrm{~min}, 2.4 \mathrm{mg}\right), \mathbf{5}\left(\mathrm{t}_{\mathrm{R}} 47.7 \mathrm{~min}, 2.8 \mathrm{mg}\right)$, a mixture of $\mathbf{2}$ and 3-hydroxy-4'-O-methylglabridin, and a mixture of $\mathbf{3}$ and leiocin were afforded. Compound $2\left(\mathrm{t}_{\mathrm{R}} 63.0 \mathrm{~min}, 1.6 \mathrm{mg}\right)$ and 3-hydroxy-4'-O-methylglabridin $\left(\mathrm{t}_{\mathrm{R}} 60.0\right.$ $\min , 1.0 \mathrm{mg}$ ) were separated from this mixture by HPLC $\left(\mathrm{MeCN}^{-} \mathrm{H}_{2} \mathrm{O}, 5: 5,7 \mathrm{~mL} / \mathrm{min}\right)$. The mixture of compound $\mathbf{3}\left(\mathrm{t}_{\mathrm{R}} 28.1 \mathrm{~min}, 1.7 \mathrm{mg}\right)$ and leiocin $\left(\mathrm{t}_{\mathrm{R}} 31.8 \mathrm{~min}, 2.0 \mathrm{mg}\right)$ were purified using HPLC (MeCN-MeOH- $\mathrm{H}_{2} \mathrm{O}, 10: 35: 55,7 \mathrm{~mL} / \mathrm{min}$ ). Fraction F03 (5.0 g) was subjected to a vacuum silica gel column using a gradient of increasing polarity with petroleum etheracetone and gave seven sub-fractions (F0301-F0307). Amorphigenin (7, $126 \mathrm{mg}$ ) was precipitated from sub-fraction F0304. Sub-fraction F0306 was chromatographed over Sephadex LH-20 with MeOH and yielded dabinol (8, $280 \mathrm{mg})$.

(6aS, 11aS)-2-hydroxyleiocarpin (1) was obtained as an amorphous solid: $[\alpha]_{\mathrm{D}}+111.4(c$ 0.14, $\mathrm{MeOH})$; UV (MeOH) $\lambda_{\max }(\log \varepsilon) 208$ (4.36), 300 (3.85) nm; CD (MeOH, $c 0.00011$ mol) $[\theta]_{220} 112780,[\theta]_{243}+121164,[\theta]_{302} 0,[\theta]_{326}-47100$; IR (film) $v_{\max } 3447,2970,2924$, $1499,1129 \mathrm{~cm}^{-1 ; 1} \mathrm{H}$ NMR $\left(\mathrm{CDCl}_{3}, 300 \mathrm{MHz}\right) \delta_{\mathrm{H}} 6.85(1 \mathrm{H}, \mathrm{s}, \mathrm{H}-1), 6.64(1 \mathrm{H}, \mathrm{s}, \mathrm{H}-7), 6.54$ 
$\left(1 \mathrm{H}, \mathrm{d}, J=9.9 \mathrm{~Hz}, \mathrm{H}-1^{\prime}\right), 6.36(1 \mathrm{H}, \mathrm{s}, \mathrm{H}-10), 5.83\left(2 \mathrm{H}, \mathrm{s}, \mathrm{OCH}_{2} \mathrm{O}\right), 5.51(1 \mathrm{H}, \mathrm{d}, J=9.9 \mathrm{~Hz}$, H-2'), $5.35(1 \mathrm{H}, \mathrm{d}, J=6.9 \mathrm{~Hz}, \mathrm{H}-11 \mathrm{a}), 5.08(1 \mathrm{H}, \mathrm{s}, \mathrm{OH}), 4.14(1 \mathrm{H}, \mathrm{dd}, J=10.8,4.8 \mathrm{~Hz}, \mathrm{H}-6)$, $3.55(1 \mathrm{H}, \mathrm{t}, J=10.8 \mathrm{~Hz}, \mathrm{H}-6), 3.40(1 \mathrm{H}, \mathrm{m}, \mathrm{H}-6 \mathrm{a}), 1.38$ (6H, s, H-4', H-5'); ${ }^{13} \mathrm{C}$ NMR $\left(\mathrm{CDCl}_{3}, 75 \mathrm{~Hz}\right) \delta_{\mathrm{C}} 154.3(\mathrm{C}, \mathrm{C}-10 \mathrm{a}), 148.1$ (C, C-9), 144.5 (C, C-4a), 141.7 (C, C-8), 140.4 (C, C-3), 139.5 (C, C-2), 129.1 (CH, C-2'), 117.9 (C, C-6b), 116.8 (CH, C-1'), 115.1 (CH, C-1), 111.9 (C, C-1a), 110.3 (C, C-4), 104.7 (CH, C-7), $101.3\left(\mathrm{CH}_{2}, \mathrm{OCH}_{2} \mathrm{O}\right), 93.8$ (CH, C-10), 78.8 (CH, C-11a), $77.0\left(\mathrm{C}, \mathrm{C}-3^{\prime}\right), 66.7\left(\mathrm{CH}_{2}, \mathrm{C}-6\right), 40.5(\mathrm{CH}, \mathrm{C}-6 \mathrm{a}), 27.9^{*}\left(\mathrm{CH}_{3}, \mathrm{C}-4^{\prime}\right), 27.8^{*}$ $\left(\mathrm{CH}_{3}, \mathrm{C}-5^{\prime}\right)(*$ assignments are interchangeable); HRESIMS $\mathrm{m} / z 389.0974$ (calcd for $\left.\mathrm{C}_{21} \mathrm{H}_{18} \mathrm{O}_{6} \mathrm{Na}, 389.0996\right)$.

Discoloranone A (2) was obtained as an amorphous solid: $[\alpha]_{\mathrm{D}} 0(c 0.09, \mathrm{MeOH}) ; \mathrm{UV}(\mathrm{MeOH})$

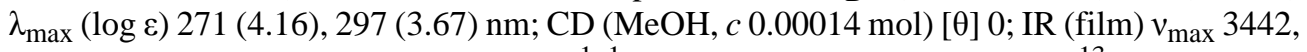
2968, 2921, 1635, 1473, 1373, $1175 \mathrm{~cm}^{-1 ; 1} \mathrm{H} \mathrm{NMR}\left(\mathrm{CDCl}_{3}, 400 \mathrm{MHz}\right)$ and ${ }^{13} \mathrm{C} \mathrm{NMR}$ $\left(\mathrm{CDCl}_{3}, 100 \mathrm{MHz}\right.$ ), see Table 1; HRESIMS $\mathrm{m} / z 405.0936$ (calcd for $\mathrm{C}_{21} \mathrm{H}_{18} \mathrm{O}_{7} \mathrm{Na}, 405.0945$ ).

(3S)-isodiscoloranone A (3) was obtained as an amorphous solid: $[\alpha]_{\mathrm{D}}-12.5(c 0.08, \mathrm{MeOH})$; $\mathrm{UV}(\mathrm{MeOH}) \lambda_{\max }(\log \varepsilon) 270$ (4.17), $296(3.81) \mathrm{nm} ; \mathrm{CD}(\mathrm{MeOH}, c 0.00018 \mathrm{~mol})[\theta]_{241} 8919$, $[\theta]_{241}+5230,[0]_{279} 0,[\theta]_{307}-2677$; IR (film) $v_{\max } 3442,2964,1637,1483,1175 \mathrm{~cm}^{-1 ; 1} \mathrm{H}$ NMR $\left(\mathrm{CDCl}_{3}, 400 \mathrm{MHz}\right)$ and ${ }^{13} \mathrm{C} \mathrm{NMR}\left(\mathrm{CDCl}_{3}, 100 \mathrm{MHz}\right)$, see Table 1 ; HRESIMS $\mathrm{m} / \mathrm{z}$ 405.0950 (calcd for $\mathrm{C}_{21} \mathrm{H}_{18} \mathrm{O}_{7} \mathrm{Na}, 405.0945$ ).

(3S)-discoloranone B (4) was obtained as an amorphous solid: $[\alpha]_{\mathrm{D}}+6.7($ c $0.12, \mathrm{MeOH})$; UV $(\mathrm{MeOH}) \lambda_{\max }(\log \varepsilon) 271$ (4.14), 295 (sh) (3.77) nm; CD (MeOH, $\left.c 0.00022 \mathrm{~mol}\right)[\theta]_{269}+9356$, $[\theta]_{290} 0,[\theta]_{312}-3739$; IR (film) $v_{\max } 3442,2968,1647,1457,1374,1162 \mathrm{~cm}^{-1 ; 1} \mathrm{H}$ NMR $\left(\mathrm{CDCl}_{3}, 400 \mathrm{MHz}\right)$ and ${ }^{13} \mathrm{C} \mathrm{NMR}\left(\mathrm{CDCl}_{3}, 100 \mathrm{MHz}\right)$, see Table 2; HRESIMS $m / z$ 475.1719 (calcd for $\mathrm{C}_{26} \mathrm{H}_{28} \mathrm{O}_{7} \mathrm{Na}, 475.1727$ ).

(3S)-isodiscoloranone (5) was obtained as an amorphous solid: $[\alpha]_{\mathrm{D}^{+13}}+2($ c $0.19, \mathrm{MeOH})$; $\mathrm{UV}(\mathrm{MeOH}) \lambda_{\max }(\log \varepsilon) 273$ (4.35), 295 (sh) (3.96) nm; CD (MeOH, $\left.c 0.00023 \mathrm{~mol}\right)[\theta]_{270}$ +11633, $[\theta]_{297} 0,[\theta]_{311}-3882$; IR (film) $v_{\max } 3442,2968,2924,1644,1456,1386,1164$ $\mathrm{cm}^{-1 ; 1} \mathrm{H} \mathrm{NMR}\left(\mathrm{CDCl}_{3}, 400 \mathrm{MHz}\right)$ and ${ }^{13} \mathrm{C} \mathrm{NMR}\left(\mathrm{CDCl}_{3}, 100 \mathrm{MHz}\right)$, see Table 2; HRESIMS $\mathrm{m} / z 475.1709$ (calcd for $\mathrm{C}_{26} \mathrm{H}_{28} \mathrm{O}_{7} \mathrm{Na}$, 475.1727).

\section{Cytotoxicity Assay}

Fractions were tested in the LNCaP (hormone-dependent human prostate carcinoma) cell line and all isolates were evaluated in using the Lul (human lung carcinoma), LNCaP, and MCF-7 (human breast carcinoma) cancer cell lines using established protocols. ${ }^{13,14}$

\section{In Vivo Hollow Fiber Test}

Compound 6 was evaluated in the in vivo hollow fiber model at doses of 10, 20, and $40 \mathrm{mg} /$ $\mathrm{kg}$, using Lu1, LNCaP, and MCF-7 cells. ${ }^{12}$

\section{Supplementary Material}

Refer to Web version on PubMed Central for supplementary material.

\section{Acknowledgements}

This investigation was supported in part by grant U19-CA-52956, funded by the National Cancer Institute, NIH, Bethesda, MD. Fellowship support for L. K. M. to work at the University of Illinois at Chicago was kindly provided by Science Applications International Corporation, through the Visiting Scientist Fund, supported by the NCI Developmental Therapeutics Program, and by the NCI Office of International Affairs, through Courtesy Associates. We are grateful to the Nuclear Magnetic Resonance Laboratory of the Research Resources Center, University of Illinois at Chicago, for the provision of certain NMR spectroscopic facilities used in this investigation. We thank the College of Pharmacy, The Ohio State University, for the provision of NMR spectroscopic equipment used in this 
investigation. We are grateful to Dr. Christopher M. Hadad and Susan Hatcher, Mass Spectrometry Facility, Department of Chemistry, The Ohio State University, for the mass spectrometric data.

\section{References and Notes}

1. http://www.ars-grin.gov/cgi-bin/npgs/html/taxon.pl?420069.

2. El Amin, HM. Trees \& Shrubs of the Sudan. Ithaca Press; Exeter, UK: 1990. p. 289

3. http://www.worldagroforestry.org/sea/Products/AFDbases/af/SpeciesInfo.asp?SpID=326.

4. Mahunnah, R. L. A. Unpublished results.

5. Kinghorn AD, Farnsworth NR, Soejarto DD, Cordell GA, Swanson SM, Pezzuto JM, Wani MC, Wall ME, Oberlies NH, Kroll DJ, Kramer RA, Rose WC, Vite GD, Fairchild CR, Peterson RW, Wild R. Pharm Biol 2003;41(Suppl):53-67.

6. van Heerden FR, Brandt EV, Roux DG. J Chem Soc, Perkin Trans 1 1978:137-145.

7. Abe F, Donnelly DMX, Moretti C, Polonsky J. Phytochemistry 1985;24:1071-176.

8. Kinoshita T, Kajiyama K, Hiraga Y, Takahashi K, Tamura Y, Mizutani K. Heterocycles 1996;43:581588.

9. Silva GL, de Abreu Matos FJ, Silveira ER. Phytochemistry 1997;46:1059-1062.

10. Slade D, Ferreira D, Marais JPJ. Phytochemistry 2005;66:2177-2215. [PubMed: 16153414]

11. Palazzino G, Rasoanavio P, Federici E, Nicoletti M, Galeffi C. Phytochemistry 2003;53:457-459.

12. Mi Q, Lantvit D, Reyes-Lim E, Chai H, Zhao W, Lee IS, Pereza-Sanchez S, Ngassapa O, Kardono LBS, Hollingshead MG, Mayo JG, Farnsworth NR, Cordell GA, Kinghorn AD, Pezzuto JM. J Nat Prod 2002;65:842-850. [PubMed: 12088425]

13. Likhitwitayawuid K, Angerholfer CK, Cordell GA, Pezzuto JM, Ruangrungsi NJ. Nat Prod 1993;56:30-38.

14. Seo EK, Kim NC, Mi Q, Chai H, Wall ME, Wani MC, Navarro HA, Burgess JP, Graham JG, Cabieses F, Tan GT, Farnsworth NR, Pezzuto JM, Kinghorn ADJ. Nat Prod 2001;64:1483-1485. 


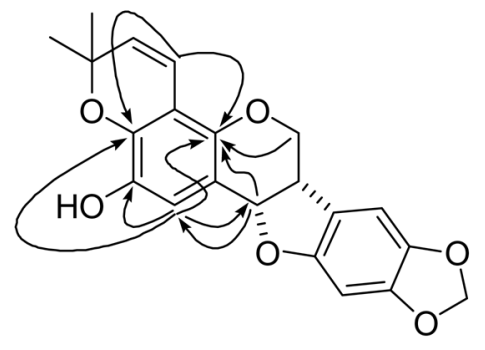

1
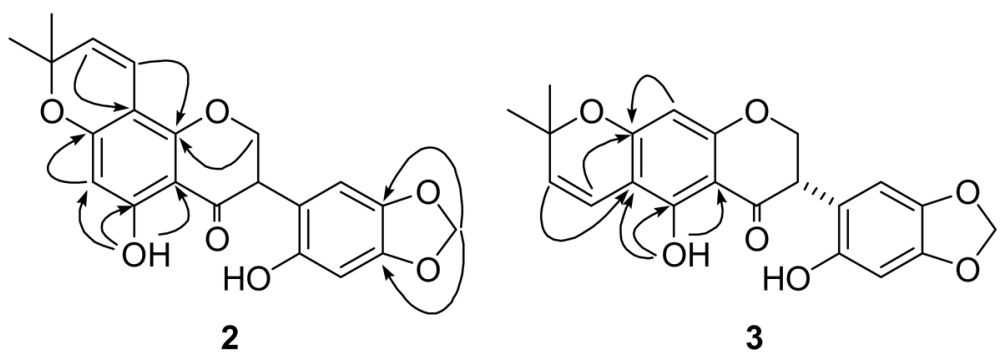

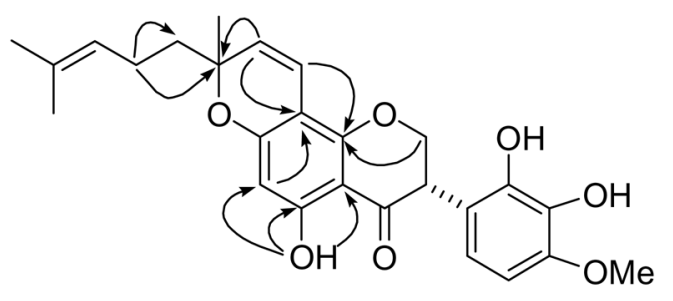

4

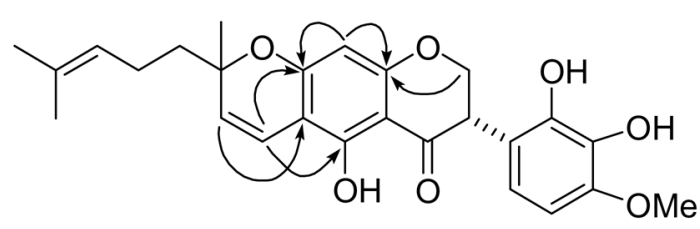

5

Figure 1.

Selected HMBC correlations of $\mathbf{1 - 5}$. 


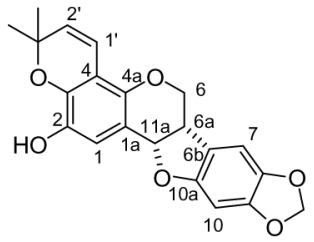

1<smiles>COc1ccc([C@H]2COc3cc4c(c(O)c3C2=O)C=CC(C)(CCC=C(C)C)O4)c(O)c1O</smiles><smiles>CC1(C)Oc2cc(O)c3c(c2O1)OC[C@H](c1cc2c(cc1O)OCO2)[C@H]3O</smiles>

2<smiles>CC1(C)C=Cc2c(cc3c(c2O)C(=O)[C@H](c2cc4c(cc2O)OCO4)CO3)O1</smiles><smiles>[3H]/C([CH])=C\CC[C@@]1(C)C=[C+]c2c(c(O)cc3c2OC[C@@H](c2ccc(OC)c(O)c2O)C3=O)O1</smiles><smiles>COc1ccc([C@@H]2COc3c(ccc4c3C=CC(C)(CCC=C(C)C)O4)C2)c(O)c1O</smiles>

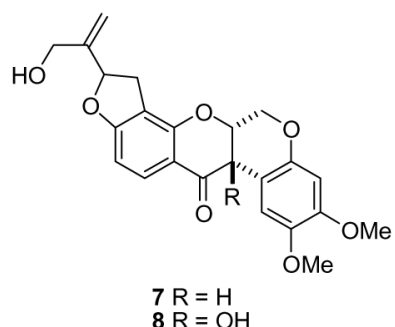


Table 1

${ }^{1} \mathrm{H}$ and ${ }^{13} \mathrm{C}$ NMR Chemical Shifts of Compounds 2 and $\mathbf{3}$ in $\mathrm{CDCl}_{3}$

\begin{tabular}{|c|c|c|c|c|}
\hline \multirow[b]{2}{*}{ position } & \multicolumn{2}{|c|}{2} & \multicolumn{2}{|c|}{3} \\
\hline & $\boldsymbol{\delta}_{\mathbf{H}}(J$ inHz $)$ & $\delta_{\mathrm{C}}$, mult. $^{a}$ & $\boldsymbol{\delta}_{\mathbf{H}}(J$ inHz $)$ & $\delta_{\mathrm{C}}$, mult. $^{a}$ \\
\hline 2 & $\begin{array}{l}4.90, \mathrm{dd}(12.0,3.1) \\
4.77, \mathrm{dd}(12.0,4.6)\end{array}$ & $69.8, \mathrm{CH}_{2}$ & $\begin{array}{l}4.83, \mathrm{dd}(12.2,3.1) \\
4.74, \mathrm{dd}(12.2,4.5)\end{array}$ & $69.8, \mathrm{CH}_{2}$ \\
\hline 3 & 3.98 , brt (3.6) & $45.0, \mathrm{CH}$ & 3.96 , brt (3.9) & $45.1, \mathrm{CH}$ \\
\hline 4 & & $196.8, \mathrm{qC}$ & & 196.8, qC \\
\hline 5 & & $165.1, \mathrm{qC}$ & & $159.5, \mathrm{qC}$ \\
\hline 6 & $5.99, \mathrm{~s}$ & $98.4, \mathrm{CH}$ & & 103.6, qC \\
\hline 7 & & $163.9, \mathrm{qC}$ & & 163.7, qC \\
\hline 8 & & $102.3, \mathrm{qC}$ & $5.99, \mathrm{~s}$ & $96.7, \mathrm{CH}$ \\
\hline 9 & & $156.8, \mathrm{qC}$ & & $162.5, \mathrm{qC}$ \\
\hline 10 & & 101.6, qC & & 101.5, qC \\
\hline $1^{\prime}$ & & $114.9, \mathrm{qC}$ & & $114.9, \mathrm{qC}$ \\
\hline $2^{\prime}$ & & $150.8, \mathrm{qC}$ & & 150.7, qC \\
\hline $3^{\prime}$ & $6.57, \mathrm{~s}$ & $100.8, \mathrm{CH}$ & $6.56, \mathrm{~s}$ & $100.7, \mathrm{CH}$ \\
\hline $4^{\prime}$ & & $148.5, \mathrm{qC}$ & & $148.5, \mathrm{qC}$ \\
\hline $5^{\prime}$ & & $142.5, \mathrm{qC}$ & & 142.5, qC \\
\hline $6^{\prime}$ & $7.01, \mathrm{~s}$ & $106.8, \mathrm{CH}$ & $7.02, \mathrm{~s}$ & $106.8, \mathrm{CH}$ \\
\hline $1^{\prime \prime}$ & 6.63, d (10.1) & $115.6, \mathrm{CH}$ & $6.58, \mathrm{~d}(10.1)$ & $115.4, \mathrm{CH}$ \\
\hline $2^{\prime \prime}$ & $5.55, \mathrm{~d}(10.1)$ & 127.1, CH & $5.51, \mathrm{~d}(10.1)$ & $126.8, \mathrm{CH}$ \\
\hline $3^{\prime \prime}$ & & $79.0, \mathrm{qC}$ & & 79.2, qC \\
\hline $4^{\prime \prime}$ & $1.45, \mathrm{~s}$ & $28.8, \mathrm{CH}_{3}$ & $1.44, \mathrm{~s}$ & $28.9, \mathrm{CH}_{3}$ \\
\hline $5^{\prime \prime}$ & $1.47, \mathrm{~s}$ & $29.0, \mathrm{CH}_{3}$ & $1.46, \mathrm{~s}$ & $28.9, \mathrm{CH}_{3}$ \\
\hline $\mathrm{OCH}_{2} \mathrm{O}$ & $5.91, \mathrm{~s}$ & 101.7, $\mathrm{CH}_{2}$ & $5.91, \mathrm{~s}$ & $101.7, \mathrm{CH}_{2}$ \\
\hline OH-5 & $\begin{array}{l}5.93, \mathrm{~s} \\
11.72, \mathrm{~s}\end{array}$ & & $\begin{array}{l}5.92, \mathrm{~s} \\
11.89, \mathrm{~s}\end{array}$ & \\
\hline
\end{tabular}

${ }^{a}$ Multiplicity was deduced from the DEPT and HMQC spectra. 
Table 2

${ }^{1} \mathrm{H}$ and ${ }^{13} \mathrm{C}$ NMR Chemical Shifts of Compounds 4 and $\mathbf{5}$ in $\mathrm{CDCl}_{3}$

\begin{tabular}{|c|c|c|c|c|}
\hline \multirow[b]{2}{*}{ position } & \multicolumn{2}{|c|}{4} & \multicolumn{2}{|c|}{5} \\
\hline & $\delta_{H}(J$ inHz $)$ & $\delta_{\mathrm{C}}$, mult. $^{a}$ & $\delta_{H}(J$ inHz $)$ & $\delta_{\mathrm{C}}$, mult. $^{a}$ \\
\hline 2 & $\begin{array}{l}4.76, \mathrm{dd}(11.1,8.7) \\
4.62, \mathrm{dd}(11.1,5.7)\end{array}$ & $70.1, \mathrm{CH}_{2}$ & $\begin{array}{l}4.72, \mathrm{dd}(10.8,8.4) \\
4.57, \mathrm{dd}(10.8,5.1)\end{array}$ & $69.9, \mathrm{CH}_{2}$ \\
\hline 3 & $4.22, \mathrm{dd}(8.7,5.7)$ & $45.9, \mathrm{CH}$ & $4.20, \mathrm{dd}(8.4,5.1)$ & $46.1, \mathrm{CH}$ \\
\hline 4 & & $196.8, \mathrm{qC}$ & & 196.8, qC \\
\hline 5 & & $164.3, \mathrm{qC}$ & & $158.9, \mathrm{qC}$ \\
\hline 6 & $6.00, \mathrm{~s}$ & $97.4, \mathrm{CH}$ & & $102.9, \mathrm{qC}$ \\
\hline 7 & & $162.8, \mathrm{qC}$ & & $162.7, \mathrm{qC}$ \\
\hline 8 & & 101.6, qC & $5.94, \mathrm{~s}$ & $95.8, \mathrm{CH}$ \\
\hline 9 & & 157.0, qC & & 162.7, qC \\
\hline 10 & & $102.5, \mathrm{qC}$ & & $102.5, \mathrm{qC}$ \\
\hline $1^{\prime}$ & & $115.0, \mathrm{qC}$ & & 115.1, qC \\
\hline $2^{\prime}$ & & $142.5, \mathrm{qC}$ & & $142.5, \mathrm{qC}$ \\
\hline $3^{\prime}$ & & $133.4, \mathrm{qC}$ & & $133.4, \mathrm{qC}$ \\
\hline $4^{\prime}$ & & $146.9, \mathrm{qC}$ & & $146.9, \mathrm{qC}$ \\
\hline $5^{\prime}$ & $6.50, \mathrm{~d}(8.1)$ & $103.5, \mathrm{CH}$ & $6.49, \mathrm{~d}(8.7)$ & 103.6, CH \\
\hline $6^{\prime}$ & $6.75, \mathrm{~d}(8.1)$ & $119.3, \mathrm{CH}$ & $6.76, \mathrm{~d}(8.7)$ & $119.3, \mathrm{CH}$ \\
\hline $1^{\prime \prime}$ & $6.63, \mathrm{~d}(10.2)$ & $115.9, \mathrm{CH}$ & $6.65, d(10.2)$ & $115.8, \mathrm{CH}$ \\
\hline $2^{\prime \prime}$ & $5.47, \mathrm{~d}(10.2)$ & $125.2, \mathrm{CH}$ & $5.45, \mathrm{~d}(10.2)$ & $124.9, \mathrm{CH}$ \\
\hline $3^{\prime \prime}$ & & $80.7, \mathrm{qC}$ & & $80.9, \mathrm{qC}$ \\
\hline 4" & $1.43, \mathrm{~s}$ & $27.3, \mathrm{CH}_{3}$ & $1.42, \mathrm{~s}$ & $27.3, \mathrm{CH}_{3}$ \\
\hline $5^{\prime \prime}$ & $1.68-1.72, \mathrm{~m}$ & $41.8, \mathrm{CH}_{2}$ & $1.68-1.72, \mathrm{~m}$ & $41.8, \mathrm{CH}_{2}$ \\
\hline $6^{\prime \prime}$ & $2.08, \mathrm{q}(7.8)$ & $22.7, \mathrm{CH}_{2}$ & $2.09, \mathrm{q}(7.7)$ & 22.6, $\mathrm{CH}_{2}$ \\
\hline 7" & 5.11, brt (7.2) & $123.7, \mathrm{CH}$ & 5. 11, brt (7.4) & $123.8, \mathrm{CH}$ \\
\hline $8^{\prime \prime}$ & & $132.0, \mathrm{qC}$ & & $131.9, \mathrm{qC}$ \\
\hline $9^{\prime \prime}$ & $1.60, \mathrm{~s}$ & $17.7, \mathrm{CH}_{3}$ & $1.59, \mathrm{~s}$ & 17.6, $\mathrm{CH}_{3}$ \\
\hline $10^{\prime \prime}$ & $1.68, \mathrm{~s}$ & $25.7, \mathrm{CH}_{3}$ & $1.68, \mathrm{~s}$ & $25.6, \mathrm{CH}_{3}$ \\
\hline $\mathrm{OH}-5$ & $12.12, \mathrm{~s}$ & & $12.30, \mathrm{~s}$ & \\
\hline $\mathrm{OCH}_{3}-4^{\prime}$ & $3.89, \mathrm{~s}$ & $56.2, \mathrm{CH}_{3}$ & $3.88, \mathrm{~s}$ & $56.2, \mathrm{CH}_{3}$ \\
\hline
\end{tabular}

${ }^{a}$ Multiplicity was deduced from the DEPT and HMQC spectra. 
Table 3

Cytotoxicity of Compounds from B. discolor against Cancer Cell Lines ${ }^{a, b}$

\begin{tabular}{ccccc}
\hline & & \multicolumn{2}{c}{ cell line $^{c}$} \\
\cline { 2 - 4 } compound & Lu1 & LNCaP & MCF-7 \\
& & 9.6 & 6.4 & 3.6 \\
$\mathbf{4}$ & 4.2 & 7.9 & 3.5 & 720 \\
$\mathbf{6}$ & 4.8 & 5.4 & 13.1 \\
$\mathbf{7}$ & 3.1 & & \\
\hline
\end{tabular}

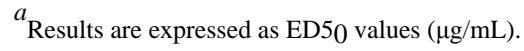

${ }^{b}$ Compounds 1-3, 5, heminitidulan, 3-hydroxy-4'- $O$-methylglabridin, 4'-hydroxycabenegrin A-I, leiocarpin, leiocin, leiocinol, and nitidulan were inactive against all cell lines $(\mathrm{ED} 50>5.0 \mu \mathrm{g} / \mathrm{mL})$.

${ }^{c}$ Key: Lu1 (human lung carcinoma); LNCaP (hormone-dependent human prostate carcinoma); MCF-7 (human breast carcinoma). 